\title{
Reproduction of Artworks in the Lippmannian-Frankfurtian Debates During Advanced Technology Era
}

\section{Reprodukowanie dzieł sztuki w erze zaawansowanych technologii w świetle debaty lippmannowsko-frankfurckiej}

\section{- Abstract •}

The development of technology leads to mechanical reproduction of artworks. This tendency brings the paradox whether mechanical reproduction of artworks enlightens or blinds society. Optimistic perspective of Walter Benjamin and Lippmannian school on reproducibility faces pessimistic view of Theodor Adorno and Max Horkheimer. Thus, the main aim of this paper is to compare W. Lippmann, W. Benjamin, T. Adorno and M. Horkheimer's views and summarize by checking suitability of two schools' perspectives in advanced technological century.

Keywords: propaganda; persuasion; manipulation; reproduction; artwork

\section{- Abstrakt •}

Rozwój technologii prowadzi do mechanicznej reprodukcji dzieł sztuki. Ta tendencja niesie ze sobą paradoks, zawierający się w pytaniu, czy mechaniczna reprodukcja dzieł sztuki prowadzi do oświecenia, czy zaślepienia społeczeństwa. Optymistyczne poglądy na reprodukowalność Waltera Benjamina oraz szkoły Lippmannowskiej kolidują z pesymistycznymi stanowiskami Theodora Adorna i Maksa Horkheimera. Dlatego głównym celem tego artykułu jest porównanie poglądów W. Lippmanna, W. Benjamina, T. Adorna i M. Horkheimera oraz sprawdzenie adekwatności dwóch odmiennych spojrzeń na tę kwestię w wieku zaawansowanej technologii.

Słowa kluczowe: propaganda; perswazja; manipulacja; reprodukcja; dzieło sztuki 


\section{Introduction}

Between 1920s and 1930s, Weimar Germany was in huge progress and innovation in politics, technology, and culture, going to attract vast numbers of scholars to cities like Berlin. Among these, representatives of the Institute for Social Research, also known as the "Frankfurt School", were highly affected by the cultural and political issues. Among other first-generation analytical thinkers, Walter Benjamin and Theodor W. Adorno gave particular attention to the implications of the artwork under new types of production and to the issue of its revolutionary potential (Kaes, Jay, \& Dimendberg, 1995).

The growth of reproductive technologies that enabled mass-produced art, such as gramophone, radio, and public cinema, created question whether such technologies should be taken as suspects immediately or whether they should be received as socially liberatory. For W. Benjamin, these technologies and the art that leads the series are inherently packed with revolutionary potential for mass participation and perceptual transformation (Benjamin, 1935). American newspaper commentator and author Walter Lippmann was also optimistic with enlightenment of society through persuasion. However, T. Adorno refers to mechanical reproduction of entertained art as an instrument of exploitation by consuming fetishized products rather than genuine artistic experiences which reveals actual problems of society.

Thus, the object of this research is to analyze this paradox between Lippmannian and Frankfurtian schools toward reproduction of artworks. The main aim of this paper is to compare W. Lippmann, W. Benjamin, T. Adorno and M. Horkheimer's views and summarize by checking suitability of two schools' perspective in advanced technological century.

Objectives:

1. To analyze contrasted opinions of W. Lippmann and W. Benjamin versus T. Adorno and M. Horkheimer.

2. To give critical interpretation by checking validity of their statements.

3. To give a conclusion as an evaluation of research.

Research method is mostly based on qualitive analysis which is a method used in political and philosophical research. Qualitative content analysis is useful to investigate news, texts, videos, and images shared on social media. Descriptive analysis is set up to research political events. Comparative analysis method assisted to find differences and similarities between the thinkers mentioned above. 


\section{Walter Benjamin's View on Reproduction of Art}

Walter Benjamin's perspective in some of his writings focuses on the political impacts of new emerging media, particularly with regard to ties with the public. A first factor to consider is the effect of the mass media on the understanding of culture. As shown by W. Benjamin, descriptive language in journalism muted the storyteller's voice, which was synonymous with the world's everyday experience. At the same time, the growth of industrial capitalism and technological reproduction led to the "desacralization" of culture, which Benjamin magisterially represented as both the disappearance and decay of the aura (Correia, 2010).

Mechanical duplication liberates the work of art from its oppressive reliance on ritual, for the very first time in human history. The effect of technology on the individual and group perception was defined by Benjamin, which demonstrates how technological reproduction changes reality in the eyes of masses. The role of art is to train people to integrate into their view the mechanized systems of contemporary life (Gumbrecht \& Marrinan, 2003). While artworks held the claim to the definitive cultural value of particular social contexts, the twentieth-century technological advancements fundamentally altered the character of art as something which was intended to be replicated and distributed on a massive scale (Kutner, 2017). The political results of reproducibility of works of art are directly related to the new role of mass-produced art in the experiences of people, namely due to the potential for mimetic activity (Benjamin, 1935).

The videotape can be reproduced and spread, the performance taken from the auditorium and made available to a wider audience. Film creates knowledge of social conditions, providing general public with new types of depiction and the unconscious impacts of group perception, which will progressively generate a truly critical mass consciousness (Miller, 1992).

The film emerges as an artistic trend believed to be politically important by Benjamin. Unlike drawing, film offers an object for common immediate practice. Individual has the opportunity to explore the daily in depth via its techniques such as slow motion and close-up. It demonstrates the small details about our daily activities and familiar environments (Benjamin, 1935).

Free from the mystification of mass culture, media culture should produce more analytical persons capable of evaluating and examining their community. W. Benjamin's thesis underlines the modern realities of creative development and reception. The new visual art has a strong potential, taking artwork closer to audience. W. Benjamin not only noticed improvements in social reception and interpretation in the visual arts. The technology field has brought about profound literary chang- 
es. The freedom to follow a literary career in journalism is now a basic human right (Correia, 2010).

In contrast, according to W. Benjamin, over centuries several thousands of readers faced a limited number of writers. With the expansion of the media, which has continued to place new political, social, science, technical and local bodies before the readers, a growing number of readers have become writers. Thus, the difference between writer and reader is about to lose its essential nature. The gap just becomes practical. The audience is willing to turn into a writer at any time (Benjamin, 1935). By being analysts and creators themselves and encouraging those whose knowledge is diminished in the context of technological progress, the people have become all the more knowledgeable and active.

The unconscious impacts of distracted perception and shock are perhaps the most critical innovative aspect of film production. As the practice of production, W. Benjamin recognizes human perception in a historical context as always developing and shifting. Thus, modern production types introduce alterations in human perceptions of new artforms. Common human perception, however, continues to fall behind, and has to keep up with the changes introduced in new production modes (Meek, 2011).

In a rather vague light, W. Benjamin seems to discuss the capital aspect of Disney's comedies, referring to the possibility of movie usurpation in the interest of fascism and industrialism. He mentions the "cult of the movie star" and the "cult of the audience" as two counter-revolutionary processes of film capital whose commodified aura leads to the buy of tickets for the cinema in joy of a particular star or person (Benjamin, 1935). The idolatry of a movie star is lucrative, because consumers purchase in their reverence the products sold by a famous film star.

Likewise, W. Benjamin also quotes the enslavement of art by fascism, where the "legitimate demands" of the masses are denied by the thinly revealed provision of free creative expression instead of genuine political depiction (Correia, 2010).

\section{Theodor Adorno and Max Horkheimer's View on Industrialism and Critique of Benjamin}

When Max Horkheimer and Theodor Adorno wrote their article in 1940 ("The Culture Industry: Enlightenment as Mass Deception"), they opposed the increasing influence of the entertainment industries, the commodification of art especially in the US where they emigrated. Because they looked suspiciously at new media such as cinema and radio, they laid the cultural field on the table in an eloquent 
language that made them feel pessimistic. T. Adorno and M. Horkheimer's articles on the cultural industry were mainly related to the developing cinema and media industries, especially Hollywood cinema and private radio stations in the United States. T. Adorno and M. Horkheimer are completely negative to the cultural industry in their article, which contrasts dramatically with the writings of their friends W. Benjamin and Bertolt Brecht, who are more ambivalent in the face of the possibilities and problems of technical duplication, mass media and the multidimensional aspects of production and reception under new conditions. They saw it as a spiral of systematic manipulation with an increasing effect of integration, and a retrospective need to adapt to that system (Horkheimer \& Adorno, 1947).

According to T. Adorno and M. Horkheimer, the first element of the concept of the cultural industry is that it integrates the audience and exposes it to a promise that is constantly repeated, but never implemented. According to them, the cultural industry constantly deceives its consumers with what it promises. This eternal cycle of promise, which constantly produces desire and holds it so that it never ends, lies at the heart of the idea that the cultural industry is a means to deceive the masses. According to T. Adorno and M. Horkheimer, all of the products of the cultural industry are designed to withhold, or even hinder, the imagination, spontaneity, fantasy and effective thinking from the audience. According to them, the consumers are separated into red, green and blue areas according to different income groups in the maps drawn by the research institutions and cannot be distinguished from the ones for propaganda and become statistical material (Raunig, 2011).

The other element of the concept of cultural industry is the understanding that actors, that is, producers of culture, are captives as employees of cultural industry institutions. According to Horkheimer and Adorno, the institutional form in which the cultural industry evolved is a gigantic music, entertainment or media company. Authors find themselves imprisoned in an institutional structure and their creativity is suppressed because of the way they work in the structure. While the helpless dependence and social control prevail in the world of workers, even the last bastion of autonomy, that is, the production of creativity, has become a matter of account, structured and stratified, and most of the actors who are thought to be rebellious are finally civilized under employee identity (Raunig, 2011).

There are distinctions in the views of T. Adorno and W. Benjamin about films. To W. Benjamin the film's collective reception asserted the ability for mass mobilization. Cultural industry, and particularly cinema, does not represent a revolutionary aim, according to Adorno, but rather gives enjoyment at best to the inattentive audience. Consequently, T. Adorno refuses to see the general has observed and underlined. The incorporation of the cultural domain into the commodity exchange 
system means that only cultural goods are made which can compete in a market system. Therefore, convergence of the emerging technologies with market competition will result in "standardization, identification and conformity". Consequently, users face the continuous propagation of the current social and cultural situations. This would lead to political delusion, manipulation and coherence, and would remove any idea of opposition. Press and mass culture are one factor preventing utopia from being realized, ruining private life, and preventing the development of autonomous minds (Adorno, 1991).

\section{Walter Lippmann and Public Opinion}

In his view presented in Public Opinion (1922), Walter Lippmann offers an average democratic perspective and emphasizes that ordinary people are innately unable to engage in rational thought. Lippmann explained his ideas by emphasizing some concepts of his book Public Opinion (1922): censorship, privacy, relationship, attention, transparency, stereotypes, defense, values, personal curiosity, transference, oppression, privilege, protection. In his work, W. Lippmann tried to reveal the picture in our heads despite the outside world. According to him, individuals see their environment indirectly. The fact that they have an idea of how fast or slow the news reaches them does not change their tendency to believe that the information is real. People's thoughts about the states in the world are shaped by the information they receive. Likewise, what they know about well-known people is nothing but a fictionalized reality. Humans do not have a real world-picture; thus, we cannot completely interpret social reality (Lippmann, 1922). Allport describes it as "normality of prejudice", which Lippmann uses in his book, "pictures in our heads" (Fiske, 2005). Lippmann calls this term "pseudo-environment". The mental images, perceptions, beliefs and expectations of individuals about a particular individual or group direct the person's point of view towards them. These stereotypes in the cognitive process affect the choices of individuals and the way they interpret information. In addition, individuals select the material according to their desires, and if the information given does not fulfill their standards which are supported by their stereotypes, the individual may decline (Beight, 2015).

In the mass media, W. Lippmann thinks of the newspaper as most relevant. As significant as they control public opinion as well as politicians, the choice of media facts and photographs is the way they construct the content. The media decides when and how to publish and what to skip, what sources to include, which sources to ignore, what choices to highlight, and how the public as a whole are connected 
to an event. The idea that "news and truth are not the similar thing and must be explicitly differentiated" is what the audience will not or cannot accept (Beight, 2015). Ruling classes present their reports in terms of further demarcation of party loyalty and further rejection of the opposing party (Slothuus, \& De Vreese, 2010).

Stereotypes, while not entirely accurate, may be effective instruments that help to establish a certain state of fiction. They make cognitive structure possible and make the universe meaningful. While their intelligence is inadequate, people may interact and articulate themselves by stereotypes with others. W. Lippmann states that the stereotype is the reflection of one's own value, the world of its own meaning (or thought). If emotional response is given to individuals or groups, stereotypes will guide behavior and guide individuals and groups. There is a real external world and its picture in people's mind. The categories, stereotypes and prejudices formed in the mind are the product of this created environment. As W. Lippmann states, one sees the world from the framework of their stereotypes. Therefore, different propaganda campaigns must be made according to personality traits. People with certain distinctive characteristics make up certain groups which have different stereotypes, psychologies (Lippmann, 1922).

\section{Discussion}

Aura means executive value of artwork, which is very individual, contradictory, and never could be used for propaganda purposes. W. Benjamin mentioned this concept in order to separate mechanical reproduction of artworks from the essential one. Therefore, it is not necessary to concentrate concern on the idea of aura which was criticized by T. Adorno. Propaganda always tries to keep its language (content) in one dimensional meaning. The conflicting artwork cannot be utilized by propagandists for persuasion purposes; thus, simplistic and pop art is preferable as a propaganda weapon.

Starting with W. Benjamin, later T. Adorno's statements on the reproduction help us to understand required persuasion techniques. In W. Benjamin's time period reproduction was related to printed banners, books, recordings. Adorno found that there is mechanical reproduction, repetition which is very influential power and manipulates our consciousness. According to Ian Maynard Begg, Ann Anas, and Suzanne Farinacci, repeated information creates a more truthful image of news in the mind of the audience. Also, repeated statements are more believable than new ones. It was called the "illusory truth effect" by Lynn Hasher, David Goldstein, and Thomas Toppino (Hasher et al., 1977). 
The improvement W. Benjamin noticed was the increasing persuasive power of pictures. He saw it as beneficial and it was a natural way for people to get their educational message out. The consensus has been seen in the statements of W. Lippmann and Edward Bernays about the importance of propaganda. They believe that the deliberate and informed manipulation of social patterns and attitudes is an integral part of a society. As E. Bernays notes, vast numbers of human beings must cooperate in this manner if they are to live together as a smoothly functioning society (Bernays, 1928). Thus, artworks are considered to be one of the important communication tools between parties, publics, and institutions.

The Internet creates possibility for discussion on social platform which increases rate of political participants (Shah et al., 2005). In this sense, a new term - participatory propaganda - is introduced to explain the current trends in persuasive communications: "Participatory propaganda is the deliberate, and systematic attempt to shape perceptions, manipulate cognitions and direct behaviour of a target audience while seeking to co-opt its members to actively engage in the spread of persuasive communications, to achieve a response that furthers the desired intent of the propagandist" (Wanless \& Berk, 2017).

Participatory propaganda changes from the transmissive mode to a circulative form where each individual will potentially become the current "originator" of material creation and dissemination, distributing persuasive information to others. The persuasive message activates, strengthens or intensifies pre-existing feelings associated with the message, which led the user to actively support it across the social platforms. "We Dance Together, We Fight Together" and "Dance for Freedom" are important slogans for the Georgian youth, who articulate their unyielding pursuit to liberate their nations from the scourge of tyranny and allow their all-inclusive and healthy club spaces. At the square in front of the Georgian Parliament in Tbilisi there was the largest rave ever seen in the city on the weekend of May 12, 2018. The rave was illegal, people gathered to condemn the vicious police attacks on Bassiani and Café Gallery in two of the most popular nightclubs of the world. The police raided the club on Saturday morning and arrested Bassiani co-founder Tato Getia and Zviad Gelbakhiani and scores of clubs. However, on the social communications channels the slogan "We Dance Together, We Fight Together" and "Dance for Freedom" were shared by thousands of people. The government had to adjust the law due to the obvious demonstrations (Biberstein, 2019).

It is known that Turkish TV series are followed with interest by the peoples of Central Asia. The first shoots of this were seen even in the Soviet Union period. The series Çalıkuşu, which was shown in the Turkic Republics at that time, was very popular, and the name of the hero of the series, Feride, was given to 
many children. Later, many TV series such as Kurtlar Vadisi and Muhteşem Yüzynl were watched with interest in the region. Cultural and ethnic partnerships, religious partnerships in the Middle East and Arab geography, and historical, cultural and ethnic partnerships in the Balkans play an important role in the popularity of Turkish TV series in Central Asia. These common aspects are important in terms of establishing emotional ties with the story and the characters represented in the series (Yilmaz \& Kilicoglu, 2018). Those TV series serve society sharing knowledge about common culture, history and value which are important factors for the stability and peace in the region. It is vital to reveal the artwork contents which demonstrate the same values in South Caucasus where people from different religion and nationality live.

As T. Adorno and W. Lippmann notes, people see the world through the image in their head and with stereotypes. This image is formulated via limited information of events. Adorno also notes that societies are separated into three different groups (red, blue, green) according to their characters which include ability to be propagandized, religions, beliefs, stereotypes, etc. Cambridge Analytica Scandal makes clear the point of T. Adorno's statement about manipulation of individuals according to political environment. The Cambridge Analytica is in the middle of a political firestorm after video recordings showed one of the company's top executives bragging about a variety of illicit methods, including psychological coercion, entrapment, and fake news promotions. Data from millions of Facebook users were without their permission obtained by British consultancy company Cambridge Analytica, and their personal information was later used for political advertising. These reports have desperate questions about whether such user records were being used to try to alter the outcomes of the 2016 U.S. Presidential Election and the Brexit vote (Meredith, 2018).

The modern communication system establishes high choice opportunity where individuals can select and share artworks. This communication ecology increases the political and social participation where people can be aware of society's problems (Van Aelst et al., 2017). However, if we consider from the pessimistic point of view of T. Adorno, political engagement emerges in high choice environment where attitude and perception play vital role in content selection process. Individual's attitude is strongly related with political and social environment where stereotypes and group interests are formed. If we consider that society has individuals with different stereotypes, it would be undeniable that high choice environment strengthens polarization, fragmentation in the process of artworks selection and dissemination. Stereotypes are the product of political, cultural, social environment which cannot always be true information, however, people will defend and 
support their own "truthiness" through finding content which suits their views. Modern and traditional media platforms provide content as a supplier according to demands of the audience which leads to deepening of radicalization and emergence of partisan media. With the strengthening of polarization in the media and society, the facts will be shared less, extremism will increase. In such a situation, the audience now accepts the information as correct without requiring any logical explanation or evidence, as it suits their interests and opinions. This causes increasing of relativism and decreasing of factual information. Polarization also drives individual to intolerance of opposing points of view. Thus, the actor has willingness to spread the "truth" he believes in and persuade others - this tendency sometimes leads to dissemination of disinformation.

\section{Conclusion}

Reproduction of the artworks in the modern communication system creates the possibility for the individuals to access informative content and engage in the political and social problems of the society. In this era, artworks which have revolutionary capacity are easily disseminated among the members of society. In this sense, participatory propaganda is useful to spread the message containing problems of the society and can be educative. Thus, reproduction of the artworks is considered a factor facilitating communication between different parties of society.

However, from the pessimistic point of view of T. Adorno, individuals of society choose the contents according to their stereotypes, political and social environment. This tendency would lead to deepening of the polarization within the society which will not be tolerant of opposing views. Thus, every party will defend their own 'truthiness' which may be false information and would lead to disinformation. As T. Adorno states, the society is manipulated according to groups or political parties where they belong.

Therefore, it would be wrong to specify which side is correct because when we analyze the statements of both parties in today's era, we see that there are deficiencies. According to the views of W. Benjamin and W. Lippmann, if the reproduction of content facilitates communication between individuals of the society, it can also break the society into different radical groups from the pessimistic notion of T. Adorno. However, in conclusion, it is possible to state that emerging and strengthening of the paradox between the Lippmannian and the Frankfurtian school is caused by the human factor rather than the reproduction of the artworks. 


\section{References:}

Adorno, T.W. (1991). On the Fetish Character in Music and the Regression of Listening. In: T.W. Adorno, The Culture Industry: Selected Essays on Mass Culture (pp. 26-52). London: Routledge.

Beight, D.C. (2015). Walter Lippmann Saw the Future in Social Media. Retrieved from: https://www.academia.edu/7609521/Walter_Lippmann_Saw_the_Future_in_Social_ Media.

Benjamin, W. (1935). The Work of Art in the Age of Mechanical Reproduction. New York: Schocken Books.

Bernays, E. (1928). Propaganda. USA: Horace Liveright.

Biberstein, T. (2019, September 18). We Dance Together, We Fight Together. Retrieved from https://crisisandcommunitas.com/?inter_art=we-dance-together-we-fight-together.

Correia, J.C. (2010). Politics, Technology and the Media: The Originality of Walter Benjamin. Retrieved from: https://www.researchgate.net/publication/265685084_ Politics_technology_and_the_media_the_originality_of_Walter_Benjamin. DOI: 10.13140/2.1.5182.0803.

Fiske, S.T. (2005). Social Cognition and the Normality of Prejudgment. In: J.F. Dovidio, P. Glick, \& L.A. Rudman (Eds.), On the Nature of Prejudice: Fifty Years after Allport (pp. 36-53). Hoboken, NJ: Blackwell Publishing.

Gumbrecht, H., \& Marrinan, M. (Eds.) (2003). Mapping Benjamin: The Work of Art in the Digital Age. Stanford, CA: Stanford University Press.

Hasher, L., Goldstein, D., \& Toppino, T. (1977). Frequency and the Conference of Referential Validity. Journal of Verbal Learning and Verbal Behavior, 16(1), 107-112. DOI: 10.1016/S0022-5371(77)80012-1.

Horkheimer, M., \& Adorno, T.W. (1947). The Culture Industry: Enlightenment as Mass Deception. Stanford, CA: Stanford University Press.

Kaes, A., Jay, M., \& Dimendberg, E. (Eds.) (1995). The Weimar Republic Sourcebook. Berkeley, CA: University of California Press.

Kutner, D. (2017). Aura, Technology, and Society: Theodor Adorno and Walter Benjamin on the Revolutionary Potential of Art. Retrieved from: https://www.academia. edu/33117627/Aura_Technology_and_Society_Theodor_Adorno_and_Walter_Benjamin_on_the_Revolutionary_Potential_of_Art?auto=download.

Lippmann, W. (1922). Public Opinion. New Brunswick, London: Transaction Publishers.

Meek, A. (2011). Trauma and Media: Theories, Histories, and Images. New York, London: Routledge.

Meredith, S. (2018, March 21). Here's Everything You Need to Know about the Cambridge Analytica Scandal. Retrieved from: https:/www.cnbc.com/2018/03/21/facebookcambridge-analytica-scandal-everything-you-need-to-know.html.

Miller, J.H. (1992). Illustration. Cambridge: Harvard University Press.

Raunig, G. (2011). Creative Industries as Mass Deception. In: G. Raunig, G. Ray, \& U. Wuggenig (Eds.), Critique of Creativity: Precarity, Subjectivity and Resistance in the 'Creative Industries' (pp. 191-203). London: Mayfly. 
Shah, D.V., Cho, J., Eveland Jr., W.P., \& Kwak, N. (2005). Information and Expression in a Digital Age: Modeling Internet Effects on Civic Participation. Communication Research, 32(5), 531-565. DOI: 10.1177/0093650205279209.

Slothuus, R., \& De Vreese, C.H. (2010). Political Parties, Motivated Reasoning, and Issue Framing Effects. The Journal of Politics, 72(3), 630-645. DOI: 10.1017/ s002238161000006x.

Van Aelst, P., Strömbäck, J., Aalberg, T., Esser, F., De Vreese, C., Matthes, J., ... \& Papathanassopoulos, S. (2017). Political communication in a high-choice media environment: a challenge for democracy? Annals of the International Communication Association, 41(1), 3-27. DOI: 10.1080/23808985.2017.1288551.

Wanless, A., \& Berk, M. (2017). Participatory Propaganda: The Engagement of Audiences in the Spread of Persuasive Communications. Retrieved from: https://www.researchgate.net/publication/329281610_Participatory_Propaganda_The_Engagement_of_ Audiences_in_the_Spread_of_Persuasive_Communications.

Yilmaz, N., \& Kilicoglu, G. (2018) Türkiye’nin Orta Asya'daki Yumuşak Gücü Ve Kamu Diplomasisi Uygulamalarinin Analizi. Türk Dünyası Araştırmaları, 119, 141-184. Retrieved from: https://dergipark.org.tr/tr/pub/tda/issue/59374/852064. 